\title{
The potential predictive value of tumor budding for neoadjuvant chemoradiotherapy response in locally advanced rectal cancer
}

\author{
Tarkan Jäger ${ }^{1}$ (D) Daniel Neureiter ${ }^{2} \cdot$ Mohammad Fallaha $^{3} \cdot$ Philipp Schredl $^{1} \cdot$ Tobias Kiesslich $^{4,5}$ • \\ Romana Urbas $^{2}$. Eckhard Klieser ${ }^{2}$. Josef Holzinger ${ }^{1} \cdot$ Felix Sedlmayer $^{6} \cdot$ Klaus Emmanuel $^{1} \cdot$ Adam Dinnewitzer $^{1}$
}

Received: 11 March 2018 / Accepted: 12 July 2018 / Published online: 1 August 2018

(c) The Author(s) 2018

\begin{abstract}
Purpose This study was conducted to investigate the potential predictive value of tumor budding for neoadjuvant chemoradiotherapy response in locally advanced rectal cancer.

Patients and methods Surgical specimens of 128 ypUICC (Union for International Cancer Control) stage 0-III mid-to-low rectal cancer patients were identified from a prospectively maintained colorectal cancer database and classified into two groups using the 10 high-power field average method: none/mild tumor budding (BD-0) and moderate/severe tumor budding (BD-1). Overall survival, relapse-free survival (RFS), and recurrence estimates were calculated using the Kaplan-Meier method and compared with the log-rank test. For RFS, a multivariable Cox's proportional hazards regression analysis was performed.

Results No $(n=20)$ or mild $(n=27)$ tumor budding (BD-0) was identified in $47(37 \%)$ and moderate $(n=52)$ or severe $(n=29)$ tumor budding (BD-1) in $81(63 \%)$ surgical specimens. Positive tumor budding (BD-1) was associated with significantly reduced $\mathrm{T}$-level downstaging $(P<0.001)$ and tumor regression $(P<0.001)$. After a median follow-up time of 7 years (range 2.9-146.7 months), BD-0 patients had more favorable 5-year RFS (90 vs. 71\%, $P=0.02$ ) and distant recurrence ( 2 vs. $12 \%, P=0.03$ ) estimates. Multivariable analyses confirmed BD-1 as a negative predictive parameter for RFS (hazard ratio $=3.44,95 \%$ confidence interval 1.23-9.63, $P=0.018$ ).

Conclusions Our data confirm tumor budding as a strong prognostic factor and its potential predictive value for neoadjuvant chemoradiotherapy response in locally advanced rectal cancer patients. This provides the opportunity to modify and individualize neoadjuvant therapy regimens for non-responders.
\end{abstract}

Keywords Neoadjuvant therapy · Tumor microenvironment · Epithelial-mesenchymal transition · Colorectal cancer . Prognostic factor

\section{„Tumor Budding" als möglicher prädiktiver Faktor für ein Ansprechen des Tumors auf die neoadjuvante Chemoradiotherapie beim lokal fortgeschrittenen Rektumkarzinom}

\section{Zusammenfassung}

Hintergrund und Ziele Die Studie untersucht die Wertigkeit des „Tumor Budding“ als möglichen prädiktiven Faktor für ein Ansprechen auf die neoadjuvante Radiochemotherapie beim lokal fortgeschrittenen Rektumkarzinom.

Tarkan Jäger and Daniel Neureiter contributed equally to this work.

A preliminary evaluation of the data shown in this manuscript was presented as a scientific poster at the $47^{\text {th }}$ World Congress of Surgery 2017 in Basel, Switzerland, 13-17 August 2017.

$\triangle$ Tarkan Jäger

ta.jaeger@salk.at

Extended author information available on the last page of the article 
Patienten und Methoden Resektionspräparate von 128 Patienten mit einem lokal fortgeschrittenen Rektumkarzinom im ypUICC (Union for International Cancer Control) Stadium 0-III wurden aus einer prospektiv angelegten Datenbank identifiziert und hinsichtlich „Tumor Budding“ in zwei Gruppen eingeteilt: BD-0 (kein bis mildes „Tumor Budding“) und BD-1 (mäßig bis hochgradiges ,Tumor Budding“). Primäre Endpunkte der Studie waren die lokale Kontrolle, die Fernmetastasierung sowie das Gesamt- und das krankheitsfreie Überleben (RFS), die mit der Kaplan-Meier-Methode berechnet und mittels Log-rank-Test auf Signifikanz geprüft wurden. Für das RFS wurde mittels Cox-Regression multivariat getestet.

Ergebnisse Die retrospektive Analyse der Resektionspräparate ergab ein BD-0 bei 47 (37\%) und ein BD-1 bei 81 Patienten (63\%). Positives „Tumor Budding“ (BD-1) war signifikant mit einer erniedrigten Ansprechrate auf die neoadjuvante Radiochemotherapie sowohl hinsichtlich T-Level-Downstaging $(P<0,001)$ als auch Tumorregression $(P<0,001)$ assoziiert. Dabei zeigten BD-0-Patienten ein signifikant besseres 5-Jahres-RFS (90 vs. 71\%; $P=0,02)$ sowie eine bessere 5-Jahres-Fernmetastasierungsrate ( 2 vs $12 \% ; P=0,03)$. In der multivariablen Analyse wurde BD-1 als negativ prädiktiver Faktor für das RFS identifiziert (HR=3,44; $95 \%$-Konfidenzintervall 1,23-9,63; $P=0,018$ ).

Schlussfolgerung Unsere Daten bestätigen die Wertigkeit des ,Tumor Budding“ als möglichen prädiktiven und prognostischen Faktor für ein Ansprechen auf die neoadjuvante Radiochemotherapie beim lokal fortgeschrittenen Rektumkarzinom. Damit könnte die Bestimmung des „Tumor Budding“ als Stratifikationsparameter für eine individualisierte neoadjuvante Therapie dienen.

Schlüsselwörter Neoadjuvante Therapie · Tumormikromilieu · Epithelial-mesenchymale Transition · Kolorektales Karzinom · Prognostische Faktoren

\section{Introduction}

The multidisciplinary approach including radiotherapy, chemotherapy, and surgery is regarded as the standard of care for locally advanced (T3/4 and/or node positive) mid-to-low rectal cancer patients $[1,2]$. Neoadjuvant regimens consisting of preoperative long-course 5-FU (5-fluorouracil) based chemoradiotherapy (CRT; 45-50.4Gy, 25-28 fractions) and preoperative short-course radiotherapy (25 Gy, five fractions) are considered the primary treatments of choice [3-5]. The CAO/ARO/AIO-94 trial demonstrated the superiority of preoperative CRT with respect to local control, treatment compliance, and overall toxicity profile, but not in overall survival benefit, when compared to postoperative CRT [2, 5]. However, in patients with a complete or near complete pathological response receiving preoperative CRT, there was an improvement in longterm outcomes independent of clinicopathologic parameters [6]. Further randomized controlled trials (SRCT, TME, FFCD9201, EORTC22912, TROG 01.04, and FOWARC) have confirmed the most beneficial impact of preoperative therapy (radiotherapy and/or chemotherapy) on local control [7-13].

Some aspects of preoperative therapy modalities such as the optimal radiotherapy fractionation, the interval between radiotherapy and surgery, or the inclusion of oxaliplatin are still under debate [13-21]. Out of seven randomized controlled studies evaluating the neoadjuvant use of oxaliplatin in the treatment of locally advanced rectal cancer, only two (FORWARC and CAO/ARO/AIO-04) demonstrated a beneficial effect on early endpoints (such as patho- logical complete response rate) $[13,19]$. Furthermore, only the CAO/ARO/AIO-04 study demonstrated a significant improvement in disease-free survival [19].

Irrespective of a reliable tumor downstaging with 15-27\% complete responders and stable local recurrence rates of $6 \%$, more than half of the patients show no or just minor response to neoadjuvant therapy and develop distant recurrences in over $25 \%$ of cases [18, 22, 23]. Non-responsiveness exposes patients to the risks of toxicity whilst delaying surgery, for no apparent benefit [24]. Pretreatment identification of these patients and implementation of an individualized neoadjuvant therapy regimen may decrease recurrence rates and reduce perioperative complications.

While the classical tumor staging system (TNM) is accepted as the strongest predictor of clinical outcome, it has certain failings in stratifying patient subsets with intermediate tumor response after neoadjuvant therapy into more meaningful prognostic groups [25]. The assessment of tumor regression grading may overcome this shortcoming by measuring the degree of cellular tumor response to neoadjuvant therapy $[6,26,27]$. Both the TNM classification and tumor regression grading are only available in the resected specimen after neoadjuvant therapy and thus are not accessible in pretreatment specimens to assist with the planning of a modified neoadjuvant therapy.

Tumor budding is a promising histomorphological prognostic factor reported in $20-40 \%$ of colorectal cancer (CRC) cases [28]. It is defined as the presence of detached isolated single cancer cells or small clusters of up to four cells at the invasive front of epithelial cancers and is associated with lymphovascular invasion, distant 


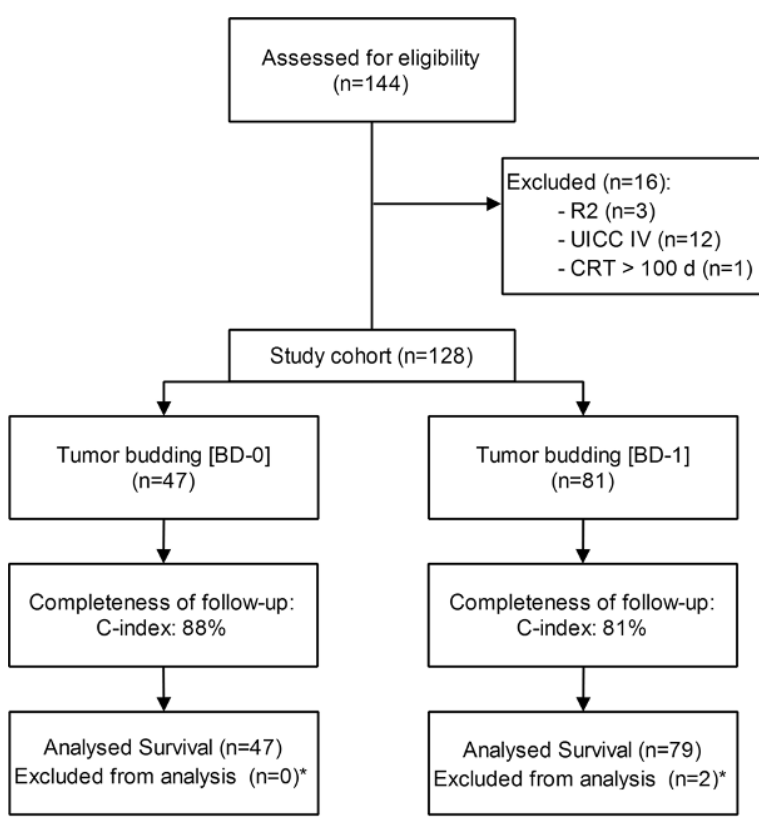

Fig. 1 Flow chart of the study population. * death within 30 days after surgery, CRT chemoradiotherapy, UICC Union for International Cancer Control

metastases, and poor prognosis [28, 29]. Tumor buds in CRC specimens represent the histological phenotype of epithelial-to-mesenchymal transition (EMT) [30, 31]. This transition is characterized by a series of cell alterations (loss of cell adhesion molecules, cytoskeletal alterations, increased production of extracellular matrix components, resistance to apoptosis, and the ability to degrade basement membrane) resulting in a phenotype with increased migratory capacity and invasiveness [32-34]. An important factor in this process is that a subset of carcinoma cells acquire the properties of stem cells, promoting long-term tumor propagation, drug resistance, and development of metastases $[35,36]$.

Some challenges and caveats exist when interpreting the role of tumor budding in neoadjuvantly treated rectal cancer patients, as most of the existing knowledge is derived from colon and historical rectal cancer patients before the era of neoadjuvant therapy regimens. There is, however, a considerable lack of knowledge about the role of tumor budding in neoadjuvantly treated rectal cancer patients, with only six published articles to date in the English literature exploring this topic [24, 29, 37-40].

The aim of this retrospective cohort study was to examine the impact of tumor budding, analyzed in the resected specimens of 128 neoadjuvantly treated mid-to-low rectal cancer patients, on long-term outcome and to evaluate its potential predictive value for neoadjuvant chemoradiotherapy (nCRT) response.

\section{Materials and methods}

\section{Patients}

The study cohort was identified from the institutional prospectively maintained colorectal cancer database including a well-characterized and previously published cohort of 144 patients [26]. All patients presented with locally advanced (cT3/4 and/or clinically node positive) mid-to-low rectal cancer who received nCRT prior to total mesorectal (TME) surgery after an interval of 4-6 weeks. Out of these 144 patients, 16 were excluded before analysis because of stage IV disease $(n=12)$, R2 resections (defined as incomplete local resection; $n=3$ ), and an interval $>90$ days between end of nCRT and TME surgery $(n=1)$. The final study cohort comprised a total of 128 consecutive non-metastasized ypUICC (Union for International Cancer Control) stage 0-III rectal cancer patients treated with longcourse nCRT and TME surgery between January 2003 and December 2012 at our tertiary care center (Fig. 1). Patients with $\mathrm{R} 1$ resection (defined as tumor present $1 \mathrm{~mm}$ or less from the radial/resection margin) remained in the study cohort. The resected specimens were assessed retrospectively with a standardized protocol for the presence of tumor budding (described below). Institutional review board approval was obtained to review records and report results.

\section{Neoadjuvant therapy}

All patients received long-course nCRT, which consisted of either oral capecitabine or intravenously administered 5-fluoruracil during 6 weeks of radiotherapy. One-hundredeleven patients $(87 \%)$ received a total dose of 45 Gy delivered in three or four high-energy photon beams by a threedimensional conformal technique, in 25 fractions with daily fractional doses of $1.8 \mathrm{~Gy}$ ( $5 \mathrm{Fx} /$ week) in 5 consecutive weeks. In ten patients (8\%), a boost to the macroscopic tumor of up to $50.4 \mathrm{~Gy}$ was applied. The remaining six patients received a reduced total dose of 40 to $44 \mathrm{~Gy}$. In approximately half of the patients $(52 \%)$, oxaliplatin was used as an adjunct to the concomitant chemotherapy. Ten patients $(8 \%$ ) were treated within the ABCSG 95 (Austrian Breast \& Colorectal Cancer Study Group) trial protocol (NCT00297141) [41, 42]. Failure to complete nCRT was an exclusion criterion.

\section{Pathologic examination and tumor budding}

Pathology specimens were examined independently by three gastrointestinal pathologists (RU, EK, and DN) who were blinded to the patient's outcome. All rectal specimens were processed macroscopically according to the national guidelines of the Austrian Society of Pathology 

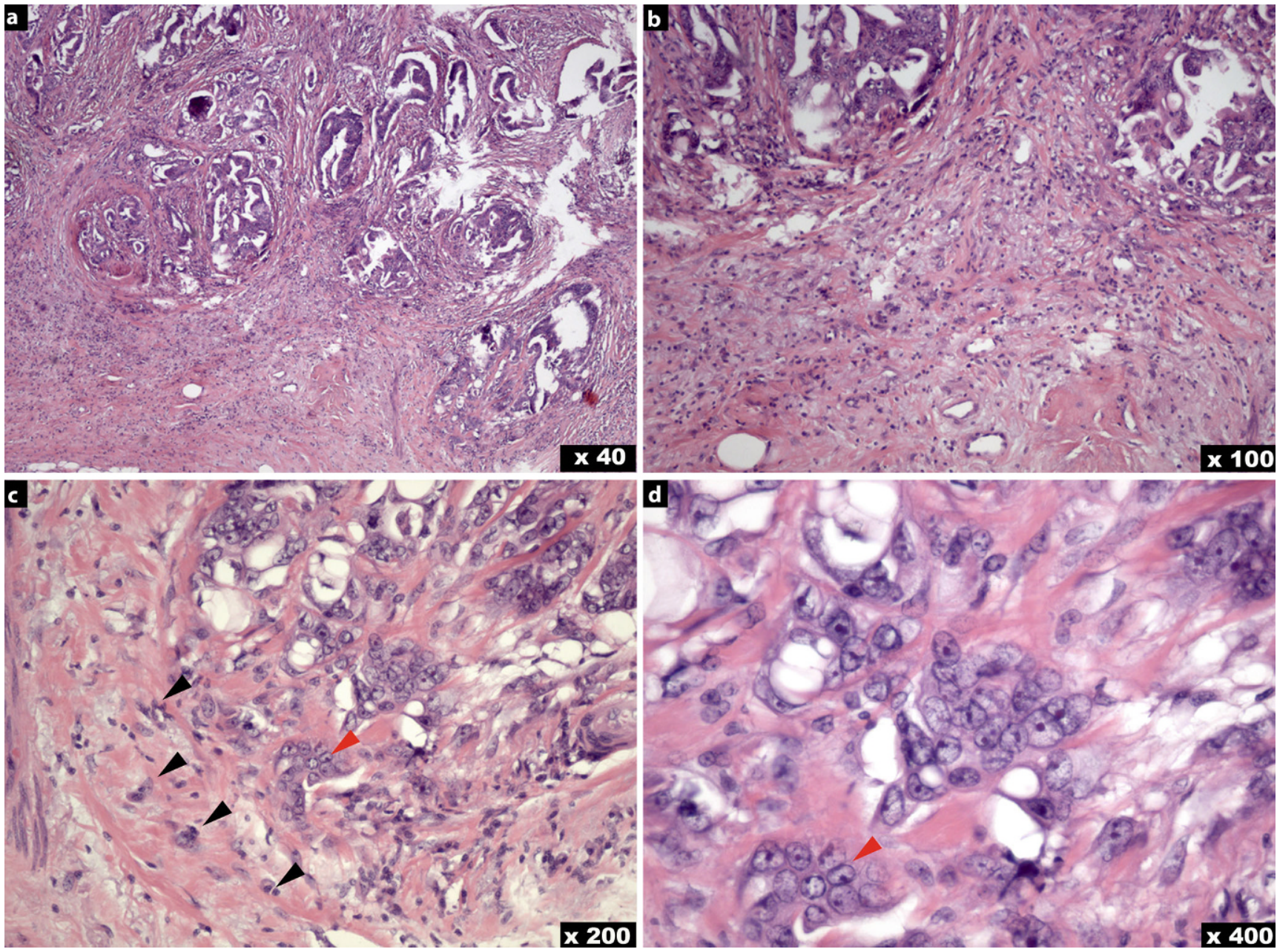

Fig. 2 Illustration of a rectal adenocarcinoma with budding. Tumor buds, defined as individual cancer cells or small clusters of tumor cells at the invasive front (arrows black/red in c, d), are illustrated. H\&E hematoxylin and eosin, original magnification $\mathbf{a}(\times 40), \mathbf{b}(\times 100), \mathbf{c}(\times 200), \mathbf{d}(\times 400)$

with details published previously [43, 44]. Completeness of resection was scored as R0 for negative margins (regardless of distance between tumor and resection margins), $\mathrm{R} 1$ for microscopic tumor present $1 \mathrm{~mm}$ or less from the radial/resection margin, and $\mathrm{R} 2$ for gross residual tumor. Pathologic stage (ypT and ypN) was determined according to the $7^{\text {th }}$ AJCC TNM classification [25]. Additionally, the pathological response of the resected specimens to nCRT was graded according the four-category TRG system developed by the American Joint Committee on Cancer and the College of American Pathologists (AJCC/CAP), published elsewhere [26]: in short, complete response (AJCC/CAP grade 0 ) is characterized by no viable cancer cells, moderate response (AJCC/CAP grade 1) by single or small groups of cancer cells, minimal response (AJCC/CAP grade 2) by residual cancer outgrown by fibrosis, and finally poor response (AJCC/CAP grade 3) by minimal or no tumor cell death with extensive residual cancer in the resected specimen.
Budding focus was defined as the presence of isolated cancer cells or clusters of up to four cancer cells either within the tumor or at the invasive tumor front [45]. As proposed by Koelzer et al. [46], the 10 high-power fields (HPF) method was applied for a quantitative assessment of tumor budding: (i) All H\&E slides with tumor areas of the resected specimen were continuously screened for the highest grade of tumor budding at low magnification $(\times 4$ up to $\times 10$ ). (ii) Based on this histomorphological preselection, tumor buds were then identified by the pathologist and counted in a total of 10 HPFs $(\times 40$; Fig. 2a-d; [47]). Consecutively, the average number of buds in these 10 HPFs was calculated. Tumor budding was categorized as "none" if there was no budding focus $(n=20)$, as "mild" if there was up to one budding focus $(n=27)$, as "moderate" if there were more than one and less than five budding foci $(n=52)$, and as "severe" if more than five budding foci $(n=29)$ could be observed in the average of 10 HPF (400 $\times$ magnification). For further statistical analyses we then formed two groups: 
Table 1 Patient characteristics

\begin{tabular}{|c|c|c|c|c|c|c|c|c|}
\hline Characteristics & \multicolumn{2}{|c|}{$\begin{array}{l}\text { All } \\
(n=128)\end{array}$} & \multicolumn{2}{|c|}{$\begin{array}{l}\text { Tumor budding } \\
\text { BD-0 }(n=47)\end{array}$} & \multicolumn{2}{|c|}{ BD-1 $(n=81)$} & \multirow{2}{*}{$\frac{P \text {-value }}{0.44}$} & \multirow[t]{2}{*}{ Tes } \\
\hline$\overline{A g e}$ & & & & & & & & \\
\hline Mean, years (SD) & 64 & $(10)$ & 63 & $(10)$ & 64 & $(10)$ & & $\mathrm{T}$ \\
\hline Gender, $n(\%)$ & & & & & & & 0.45 & \\
\hline Female & 41 & $(32)$ & 17 & $(41)$ & 24 & $(59)$ & & $\mathrm{C}$ \\
\hline Male & 87 & $(68)$ & 30 & $(34)$ & 57 & $(66)$ & & \\
\hline ASA classification, $n(\%)$ & & & & & & & 0.44 & \\
\hline 1 & 24 & (19) & 11 & $(46)$ & 13 & $(54)$ & & $\mathrm{C}$ \\
\hline 2 & 77 & $(60)$ & 25 & $(32)$ & 52 & $(68)$ & & \\
\hline 3 & 27 & $(21)$ & 11 & $(41)$ & 16 & (59) & & \\
\hline$B M I$ & & & & & & & 0.54 & \\
\hline Mean, $\mathrm{kg} / \mathrm{m}^{2}(\mathrm{SD})$ & 25.2 & (3.9) & 25.5 & $(4.1)$ & 25.0 & $(3.8)$ & & $\mathrm{T}$ \\
\hline Clinical UICC stage, $n(\%)$ & & & & & & & 0.60 & \\
\hline I & 1 & (1) & 1 & $(100)$ & 0 & $(0)$ & & $\mathrm{E}$ \\
\hline II & 57 & $(45)$ & 21 & (37) & 36 & $(63)$ & & \\
\hline III & 66 & $(52)$ & 23 & $(35)$ & 43 & $(65)$ & & \\
\hline No. missing & 4 & (3) & 2 & - & 2 & - & & \\
\hline Clinical T stage, $n(\%)$ & & & & & & & 0.008 & \\
\hline $\mathrm{T} 1$ & - & - & - & - & - & - & & $\mathrm{E}$ \\
\hline $\mathrm{T} 2$ & 3 & (2) & 2 & $(67)$ & 1 & (33) & & \\
\hline $\mathrm{T} 3$ & 107 & $(84)$ & 43 & $(40)$ & 64 & $(60)$ & & \\
\hline $\mathrm{T} 4$ & 16 & (13) & 1 & (6) & 15 & (94) & & \\
\hline No. missing & 2 & (2) & 1 & - & 1 & - & & \\
\hline Clinical $N$ stage, $n(\%)$ & & & & & & & 0.90 & \\
\hline No & 58 & $(45)$ & 22 & $(38)$ & 36 & $(62)$ & & $\mathrm{E}$ \\
\hline N1 & 56 & $(44)$ & 20 & $(36)$ & 36 & $(64)$ & & \\
\hline $\mathrm{N} 2$ & 10 & (8) & 3 & $(30)$ & 7 & $(70)$ & & \\
\hline No. missing & 4 & (3) & 2 & - & 2 & - & & \\
\hline Procedure, $n(\%)$ & & & & & & & 0.75 & \\
\hline APE & 36 & $(28)$ & 14 & (39) & 22 & $(61)$ & & $\mathrm{C}$ \\
\hline LAR & 92 & $(72)$ & 33 & $(36)$ & 59 & $(64)$ & & \\
\hline Other malignancies, $n(\%)$ & & & & & & & 0.07 & \\
\hline No & 110 & (86) & 44 & $(40)$ & 66 & $(60)$ & & $\mathrm{E}$ \\
\hline Yes & 18 & (14) & 3 & $(17)$ & 15 & $(83)$ & & \\
\hline Time: end CRT to surgery & & & & & & & 0.68 & \\
\hline Median, weeks & 5.1 & & 5.1 & & 5.1 & & & $\mathrm{M}$ \\
\hline (Range) & $(2.7-$ & & $(2.9$ & & $(2.7-$ & & & \\
\hline
\end{tabular}

$A S A$ American Society of Anesthesiologists, $A P E$ abdominoperineal excision, $B D$ tumor budding, $B M I$ body mass index, $C R T$ chemoradiotherapy, $L A R$ low anterior resection, UICC Union for International Cancer Control, $S D$ standard deviation

$C \chi^{2}$ test, $E$ Fisher's exact test, $T$ Student t-test, $M$ Mann-Whitney U test

BD-0 (none or mild tumor budding; $n=47$ ) and BD-1 (moderate or severe tumor budding; $n=81$ ).

\section{Follow-up and oncologic outcomes}

Patient follow-up was performed according to the guidelines of the Austrian Society of Surgical Oncology [48]. Outcome measures assessed in this study included survival estimates (overall [OS] and relapse-free survival [RFS]) and recurrence rates (overall [OR], distant [DR], and local re- currence $[\mathrm{LR}])$. Time-to-event endpoints were calculated from the date of primary surgery. Overall survival was defined as time to death, irrespective of cause, and RFS as the time between surgery and the first recurrence event or death, irrespective of cause. Relapse of disease was defined as pathological, radiological, or clinical determination of rectal cancer recurrence confined to the prior pelvic treatment field (LR) or at any other site, including but not limited to the liver, lungs, and retroperitoneum (DR). 
Table 2 Pathological characteristics

\begin{tabular}{|c|c|c|c|c|c|c|c|c|}
\hline \multirow{2}{*}{$\frac{\text { Characteristics }}{A J C C / C A P T R G, n(\%)}$} & $\begin{array}{l}\text { All } \\
(n=128)\end{array}$ & & \multicolumn{2}{|c|}{$\begin{array}{l}\text { Tumor Budding } \\
\text { BD-0 }(n=47)\end{array}$} & \multicolumn{2}{|c|}{ BD-1 $(n=81)$} & \multirow{2}{*}{$\frac{P \text {-value }}{<0.001}$} & \multirow[t]{2}{*}{ Test } \\
\hline & & & & & & & & \\
\hline 0 & 16 & (13) & 16 & $(100)$ & 0 & $(0)$ & & $\mathrm{E}$ \\
\hline 1 & 39 & $(30)$ & 26 & $(67)$ & 13 & (33) & & \\
\hline 2 & 54 & $(42)$ & 3 & (6) & 51 & (94) & & \\
\hline 3 & 19 & (15) & 2 & (11) & 17 & $(89)$ & & \\
\hline Histologic grade, $n(\%)$ & & & & & & & 0.15 & \\
\hline Well/moderate & 106 & (83) & 42 & $(40)$ & 64 & $(60)$ & & $\mathrm{E}$ \\
\hline Poor & 22 & $(17)$ & 5 & (23) & 17 & (77) & & \\
\hline ypUICC, $n(\%)$ & & & & & & & $<0.001$ & \\
\hline 0 & 15 & (12) & 15 & $(100)$ & 0 & $(0)$ & & $\mathrm{E}$ \\
\hline I & 38 & $(30)$ & 22 & $(58)$ & 16 & $(42)$ & & \\
\hline II & 38 & $(30)$ & 3 & (8) & 35 & $(92)$ & & \\
\hline III & 37 & (29) & 7 & (19) & 30 & $(81)$ & & \\
\hline Pathologic T stage, $n(\%)$ & & & & & & & $<0.001$ & \\
\hline $\mathrm{T} 0$ & 16 & (13) & 16 & $(100)$ & 0 & $(0)$ & & $\mathrm{E}$ \\
\hline $\mathrm{T} 1$ & 7 & (5) & 5 & $(71)$ & 2 & $(29)$ & & \\
\hline $\mathrm{T} 2$ & 36 & $(28)$ & 19 & (53) & 17 & $(47)$ & & \\
\hline $\mathrm{T} 3$ & 64 & $(50)$ & 7 & $(11)$ & 57 & $(89)$ & & \\
\hline $\mathrm{T} 4$ & 5 & (4) & 0 & $(0)$ & 5 & $(100)$ & & \\
\hline Pathologic N stage, $n(\%)$ & & & & & & & 0.01 & \\
\hline $\mathrm{N}-$ & 92 & $(72)$ & 40 & (43) & 52 & $(57)$ & & $\mathrm{C}$ \\
\hline $\mathrm{N}+$ & 36 & (28) & 7 & (19) & 29 & $(81)$ & & \\
\hline Nodes examined & & & & & & & 0.54 & \\
\hline Median (range) & 14 & $(0-33)$ & 14 & $(0-27)$ & 14 & $(3-33)$ & & M \\
\hline Mean (SD) & 13.6 & $(5.9)$ & 13.1 & $(5.7)$ & 14 & $(6.0)$ & & \\
\hline Nodes involved & & & & & & & 0.02 & \\
\hline Median (range) & 0 & $(0-14)$ & 0 & $(0-12)$ & 0 & $(0-14)$ & & M \\
\hline Mean (SD) & 1 & $(2.4)$ & 0.6 & (2) & 1.2 & $(2.5)$ & & \\
\hline Lymphatic invasion, $n(\%)$ & & & & & & & 0.003 & \\
\hline No & 90 & $(83)$ & 40 & $(44)$ & 50 & $(56)$ & & $\mathrm{E}$ \\
\hline Yes & 19 & $(17)$ & 2 & $(11)$ & 17 & $(89)$ & & \\
\hline No. missing & 19 & & 5 & & 14 & & & \\
\hline Venous invasion, $n(\%)$ & & & & & & & 0.13 & \\
\hline No & 105 & (95) & 42 & $(40)$ & 63 & $(60)$ & & $\mathrm{E}$ \\
\hline Yes & 6 & (5) & 0 & $(0)$ & 6 & $(100)$ & & \\
\hline No. missing & 17 & & 5 & & 12 & & & \\
\hline Adjuvant Chemotherapy, $n(\%)$ & & & & & & & 0.70 & \\
\hline No & 57 & $(45)$ & 22 & $(39)$ & 35 & $(61)$ & & $\mathrm{C}$ \\
\hline Yes & 71 & $(55)$ & 25 & (35) & 46 & $(65)$ & & \\
\hline$C R M, n(\%)$ & & & & & & & 0.09 & \\
\hline$>1 \mathrm{~mm}$ & 121 & (95) & 46 & (38) & 75 & $(62)$ & & $\mathrm{E}$ \\
\hline$\leq 1 \mathrm{~mm}$ & 6 & (5) & 0 & $(0)$ & 6 & $(100)$ & & \\
\hline No. missing & 1 & & 1 & & 0 & & & \\
\hline
\end{tabular}

AJCC American Joint Committee on Cancer, $B D$ tumor budding, CAP College of American Pathologists, CRM circumferential resection margin, $T R G$ tumor regression grading, UICC Union for International Cancer Control, $S D$ standard deviation

$C \chi^{2}$ test, $E$ Fisher's exact test, $M$ Mann-Whitney U test 


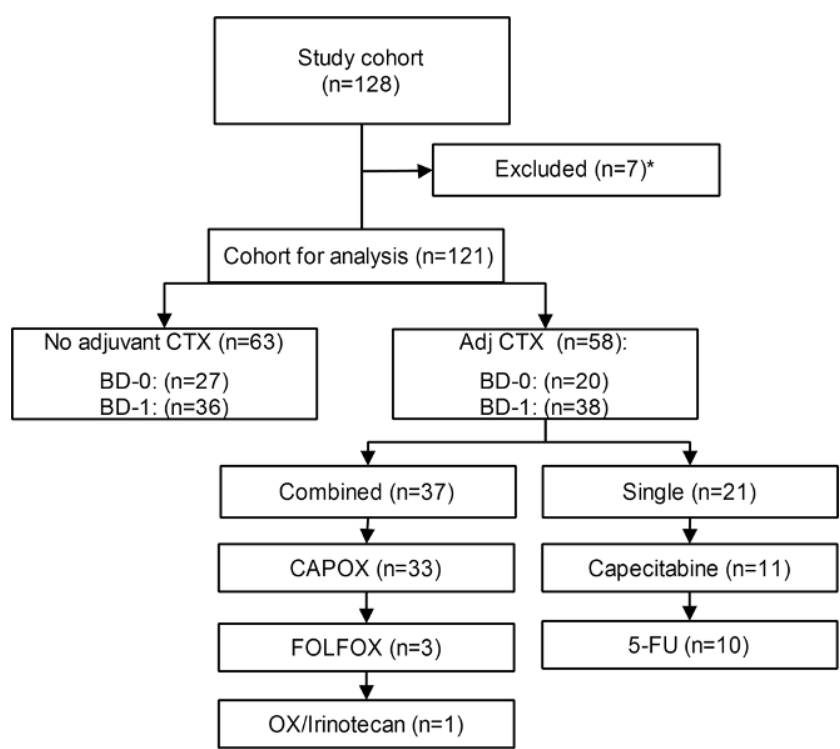

Fig. 3 Flow chart of adjuvant chemotherapy in 128 neoadjuvant chemoradiotherapy treated locally advanced rectal cancer patients. * death within 30 days after surgery $(n=2)$, adjuvant chemotherapy status not available $(n=5), A d j$ adjuvant, $B D$ tumor budding, $C T X$ chemotherapy, $C A P O X$ capecitabine combined with oxaliplatin, FOLFOX folinic acid combined with 5-fluorouracil and oxaliplatin, 5-FU 5-fluorouracil, $O X$ oxaliplatin

\section{Statistical analysis}

Clinicopathological characteristics were compared between the two groups BD-0 and BD-1. Statistical significance in differences of clinicopathological variables were tested with the independent samples t-test and Mann-Whitney U test for normally and non-normally distributed data, respectively. For the comparison of proportions, the $\chi^{2}$ test or Fisher exact test were used, as appropriate.

For the analyses of the 5-year survival and recurrence estimates, all events after 60 months of follow-up and patients with a date of last contact more than 60 months after diagnosis were censored at 60 months. Loss to follow-up was assessed with the completeness of follow-up index $\mathrm{C}$ as described by Clark et al. [49]. This index quantifies the effect of losses to follow-up as the ratio of the total observed person-time of follow-up as a percentage of the potential time of follow-up. OS, RFS, and recurrence rates were estimated using the Kaplan-Meier method and compared with the log-rank test.

For RFS, a multivariable Cox proportional hazards model was calculated to adjust for baseline differences between BD-0 and BD-1 groups. All the predictors which had a $P$-value $\leq 0.10$ in the univariate analyses were put in a forward step procedure into the model by keeping variables with a $P<0.05$ and excluding those with a $P>0.05$. All the tests are two-sided, and a $P$-value $<0.05$ indicates a statistically significant difference. Statistical analyses were performed with STATA release 14.2 (StataCorp LLC, College Station, TX).

\section{Results}

\section{Patients}

The clinical pretreatment characteristics and pathologic outcomes of the tumors in the BD-0 and BD-1 groups are shown in Tables 1 and 2. Between January 2003 and December 2012, 128 patients (87 males) with a mean age of 64 years (range 34-84 years) were identified for this retrospective cohort study. After a median interval of 5.1 weeks (range 2.7-9.3 weeks) from the end of nCRT, a low anterior (72\%, 92 of 128) or an abdominoperineal rectal resection with TME (28\%, 36 of 128) was performed. Six patients $(5 \%)$ had positive circumferential resection margin involvement, defined as microscopic evidence of tumor cells $1 \mathrm{~mm}$ or less from the margin.

Of the 128 patients, $47.9 \%$ (58 of 121) subsequently received adjuvant chemotherapy, consisting of fluoropyrimidine (5-FU/leucovorin or capecitabine) in all patients except one. Sixty-four percent ( 37 of 58 patients) of those receiving adjuvant chemotherapy additionally received oxaliplatin. The proportion of patients receiving adjuvant chemotherapy did not differ significantly between BD-0 and BD-1 groups $(P=0.35$; Fig. 3$)$.

\section{Tumor budding and response}

None $(n=20)$ or mild $(n=27)$ tumor budding (BD-0) was identified in the specimens of $47(37 \%)$ patients and moderate $(n=52)$ or severe $(n=29)$ tumor budding (BD- 1$)$ in 81 patients $(63 \%)$. There were 43 patients $(33.6 \%)$ with no downstaging effect (T-level or nodal downstaging). Positive tumor budding (BD-1) was associated with significantly reduced $\mathrm{T}$-level downstaging $(P<0.001)$ and tumor regression as assessed by the four-tier AJCC/CAP tumor regression grading system $(P<0.001)$ [50]. With regards to tumor regression, a complete response with no residual viable tumor cells was achieved in 16 patients $(13 \%)$ and a moderate response in 39 patients (30\%), with only a single or small groups of cancer cells remaining. Nevertheless, over half of the patients had either minimal $(42 \%, 54$ of 128$)$ or poor response $(15 \%, 19$ of 128$)$.

Patients with BD-1 had a statistically significant association with AJCC/CAP tumor regression grade $(P<0.001)$, ypT $(P<0.001)$, ypN $(P=0.01)$, nodal involvement $(P=0.02)$, lymphatic invasion $(P=0.003)$, and ypUICC stage $(P<0.001$; Table 2). 
a

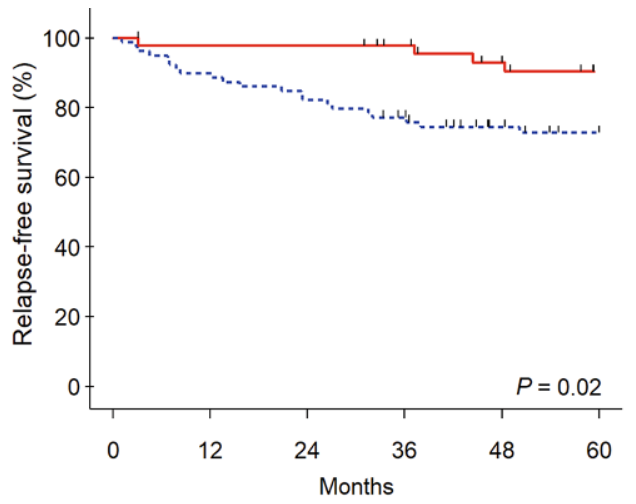

Number at risk

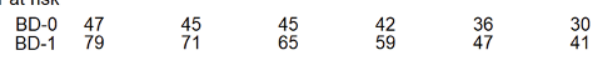

Degree of
umor budding (BD)

- BD-0

- BD-1 b

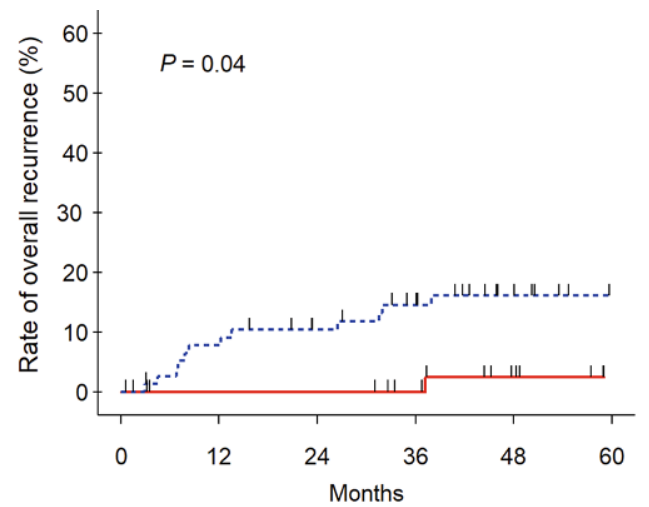

Number at risk
Degree of tumor budding (BD)

- BD-0

- BD-1

c

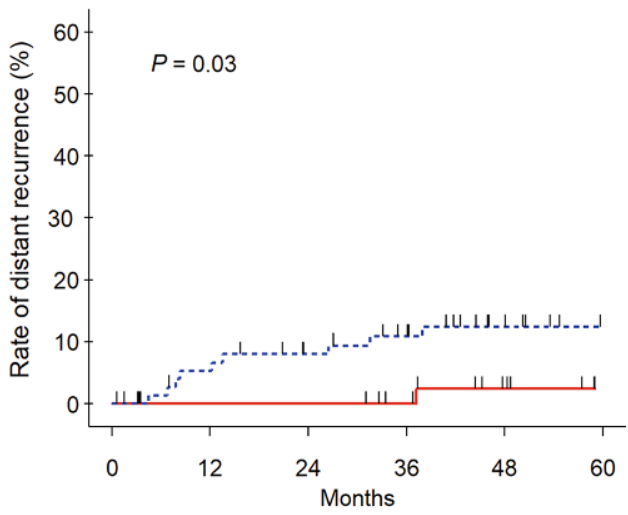

Degree of
Tumor budding (BD)

- BD-0

-- BD-1

Number at risk

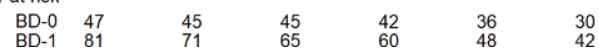

Fig. 4 Rates of 5-year relapse-free survival (a), overall recurrence (b), and distant recurrence (c) of 128 patients diagnosed with locally advanced non-metastasized rectal cancer who underwent preoperative chemoradiotherapy combined with total mesorectal excision

Table 3 Five-year survival and recurrence estimates

\begin{tabular}{|c|c|c|c|c|c|c|c|c|c|}
\hline \multirow{3}{*}{$\frac{\text { Parameter }}{\text { Overall survival }}$} & \multirow{3}{*}{$\frac{\text { Events }}{20}$} & \multirow{3}{*}{$\begin{array}{l}n \\
126\end{array}$} & \multicolumn{6}{|c|}{ 5-year estimates $(95 \% \mathrm{CI})$} & \multirow{3}{*}{$\frac{P \text {-value }^{\mathrm{b}}}{0.09}$} \\
\hline & & & \multicolumn{2}{|c|}{ All grades ${ }^{\mathrm{a}}$} & \multicolumn{2}{|c|}{ BD-0 $(n=47)$} & \multicolumn{2}{|c|}{ BD-1 $(n=81)$} & \\
\hline & & & 84 & $(76-89)$ & 90 & $(76-96)$ & 80 & $(69-87)$ & \\
\hline Relapse-free survival & 27 & 126 & 78 & $(70-84)$ & 90 & $(76-96)$ & 71 & $(60-80)$ & 0.02 \\
\hline Overall recurrence & 15 & 126 & 11 & $(7-18)$ & 2 & $(0-16)$ & 16 & $(9-26)$ & 0.04 \\
\hline Local recurrence & 6 & 126 & 5 & $(2-11)$ & 0 & - & 7 & $(3-17)$ & 0.27 \\
\hline Distant recurrence & 12 & 126 & 9 & $(5-16)$ & 2 & $(0-16)$ & 12 & $(7-23)$ & 0.03 \\
\hline
\end{tabular}

${ }^{a}$ Values shown are percentages and $95 \%$ confidence interval estimates $(95 \% \mathrm{CI})$

${ }^{\mathrm{b}}$ Log-rank test, $B D$ tumor budding

\section{Follow-up and events}

All patients were followed at least for 5 years or to the date of death or loss to follow-up. A complete follow-up was achieved in $83 \%$ of patients as assessed by the completeness of follow-up index $\mathrm{C}$ as described by Clark et al. [49]. During the median follow-up time of 7 years (range 2.9-146.7 months), twenty patients (15.6\%; BD-0: $n=4$ and BD-1: $n=16$ ) died. Of these, six patients (30\%; BD-0: $n=1$ and BD-1: $n=5$ ) died within the first year. Overall tumor recurrence was diagnosed in 15 of the 128 patients $(11.7 \%$; BD-0: $n=2$ and BD-1: $n=13$ ). Locoregional recurrence occurred in six $(4.7 \%)$, distant metastasis in twelve $(9.4 \%)$, and combined locoregional and distant recurrence in three patients $(2.3 \%)$. 
Table $4 \quad P$-values of univariate Kaplan-Meier analysis of patient, tumor, and treatment characteristics

\begin{tabular}{|c|c|c|}
\hline Parameter & $\begin{array}{l}\text { 5-year RFS } \\
(\%)\end{array}$ & $P$-value ${ }^{\mathrm{a}}$ \\
\hline$B D$ & & 0.015 \\
\hline None/minimal (BD-0) & 90 & \\
\hline Moderate/severe (BD-1) & 71 & \\
\hline Age, years & & 0.03 \\
\hline$\leq 64$ & 86 & \\
\hline$>64$ & 68 & \\
\hline Gender & & 0.23 \\
\hline Female & 85 & \\
\hline Male & 74 & \\
\hline ASA classification & & 0.002 \\
\hline ASA 1 and 2 & 84 & \\
\hline ASA 3 & 54 & \\
\hline$B M I\left(\mathrm{~kg} / \mathrm{m}^{2}\right)$ & - & 0.64 \\
\hline Surgical procedure & & 0.05 \\
\hline APE & 67 & \\
\hline LAR & 82 & \\
\hline Laparoscopic & & 0.08 \\
\hline No & 73 & \\
\hline Yes & 88 & \\
\hline Adjuvant chemotherapy & & 0.22 \\
\hline No & 73 & \\
\hline Yes & 83 & \\
\hline Time CRT to surgery (weeks) & - & 0.97 \\
\hline Other malignancies ${ }^{b}$ & & 0.01 \\
\hline No & 81 & \\
\hline Yes & 61 & \\
\hline ypUICC & & 0.01 \\
\hline $0 / \mathrm{I}$ & 86 & \\
\hline II & 67 & \\
\hline III & 78 & \\
\hline$y p T$ & & 0.02 \\
\hline $0 / 1 / 2$ & 87 & \\
\hline $3 / 4$ & 70 & \\
\hline ypN-/+ & & 0.84 \\
\hline Negative & 78 & \\
\hline Positive & 78 & \\
\hline Angiolymphatic invasion & & 0.97 \\
\hline No & 77 & \\
\hline Yes & 76 & \\
\hline Grading & & 0.80 \\
\hline 1 & 100 & \\
\hline 2 & 78 & \\
\hline 3 & 77 & \\
\hline
\end{tabular}

Table 4 (Continued)

\begin{tabular}{lll}
\hline Parameter & $\begin{array}{l}5 \text {-year RFS } \\
(\%)\end{array}$ & $P$-value $^{\mathrm{a}}$ \\
\hline$C R M$ & & $<\mathbf{0 . 0 0 1}$ \\
$>1 \mathrm{~mm}$ & 80 & \\
$\leq 1 \mathrm{~mm}$ & 33 & \\
\hline
\end{tabular}

ASA American Society of Anesthesiologists, BMI body mass index, $B D$ tumor budding, $C R T$ chemoradiotherapy, $C R M$ circumferential resection margin, RFS relapse-free survival, UICC Union for International Cancer Control

${ }^{a}$ Log-rank test. Parameters eligible for multivariate analysis ( $p$-value $\leq 0.10$ ) are indicated in bold

${ }^{\mathrm{b} D i a g n o s i s}$ of another malignant disease before $(n=6)$, at $(n=6)$, and after $(n=6)$ surgery for rectal cancer

\section{Time to event analyses}

BD-1 patients had a considerably poorer 5-year RFS, OR, and DR rates compared to BD-0 patients (RFS: $71 \%$ vs. $90 \% ; P=0.02$; OR: $16 \%$ vs. $2 \% ; P=0.04$; and DR: $12 \%$ vs. $2 \% ; P=0.03$, respectively; Fig. $4 \mathrm{a}-\mathrm{c}$, Table 3 ). In univariate analyses, several variables, i.e., tumor budding, ASA classification, secondary malignancies, age, ypT, and circumferential resection margin, were significantly associated $(P<0.05)$ with RFS (Table 4). In multivariate analysis, only tumor budding, ASA classification, and circumferential resection margin were independently prognostic for RFS (Table 5). The results from this study failed to demonstrate a statistically significant association between BD-1 and OS and $\operatorname{LR}(P=0.09$ and $P=0.13$, respectively).

\section{Discussion}

Tumor budding has been described most extensively in early and advanced colorectal cancer, implicating several scenarios in which this morphological feature might influence clinical decision making [33]. First, tumor budding could serve as a predictor of lymph node metastases in malignant polyps, which would suggest the need for resection. Second, budding may be indicative of tumor progression in stage II colorectal cancer to stratify for adjuvant therapy. Finally, tumor budding could be relevant as a predictor of tumor response to neoadjuvant therapy in pretreatment biopsies of locally advanced rectal cancer specimens [45, 46].

The first step in the development of a tumor bud seems to be its detachment from the main tumor body by loss of the adhesion molecule E-cadherin [51]. Overall, EMT is implicated in the underlying molecular mechanism of budding, which includes loss of E-cadherin in addition to the expression of fibronectin in the cytoplasm. These changes are suggestive of a more mesenchymal phenotype and also suggest a more aggressive tumor bud [51,52]. Dysregulation of cell 
Table 5 Multivariate analysis of factors influencing relapse free survival

\begin{tabular}{lllll}
\hline & \multicolumn{5}{c}{$95 \%$ CI for HR } \\
& HR & Lower & Upper & $P$-value \\
\hline $\begin{array}{l}\text { Tumor budding } \\
\text { BD-0 (none/mild) }\end{array}$ & 1 & - & - & 0.02 \\
BD-1 (moderate/severe) & 3.44 & 1.23 & 9.63 & - \\
ASA classification & & & & - \\
ASA 1 and 2 & 1 & - & - & - \\
ASA 3 & 3.23 & 1.48 & 7.08 & - \\
CRM & & & & 0.003 \\
$>1 \mathrm{~mm}$ & 1 & - & - & - \\
$\leq 1 \mathrm{~mm}$ & 3.09 & 1.21 & 7.89 & - \\
\hline
\end{tabular}

$A S A$ American Society of Anesthesiologists, $B D$ tumor budding, $C I$ confidence interval, $C R M$ circumferential resection margin, $H R$ hazard ratio, $R F S$ relapse free survival stemness phenotype (e.g., $\beta$-catenin and CD133), cell-cell interaction (e.g., CD44 and E-cadherin), and cell-matrix interaction (e.g., matrix metalloproteinase) as well as of inflammation (e.g., cytotoxic T cells) are essentially involved in tumor budding [53]. Analysis of these markers in pretreatment (and rarely post-pretreatment) specimens of colorectal cancer suggests that they could be linked to radiochemoresistance via selective EMT properties [24, 54, 55]. Based on observations of existing precursors, it has been hypothesized that the EMT process is initiated through alterations induced by radiotherapy $[24,56]$. It remains unclear how the underlying molecular mechanisms observed in EMT - and therefore in tumor budding - could either influence the effectiveness of chemoradiotherapy or, in turn, be influenced by chemoradiotherapy [57]. This was not, however, the purpose of the present study.

The aim of this study was to assess the impact of tumor budding, analyzed in surgical specimens, on oncological outcome and its possible role as a stratification parameter for a modified neoadjuvant therapy in chemoradiationinsensitive non-metastasized locally advanced mid-to-low rectal cancer patients.

Our data demonstrate a significant correlation between tumor budding, tumor regression, and downstaging after nCRT. In this respect, the current findings are consistent with the existing scarce literature investigating the role of tumor budding in neoadjuvantly treated rectal cancer patients (Table 6; [24, 37-40]).

In our cohort, we observed a T-level downstaging in $51.6 \%$ (65 of 126) of patients, together with an N-level downstaging in $65.2 \%$ (43 of 66 clinically involved lymph nodes) of patients, accounting for an overall response rate (T-level or N-level downstaging) of $64.3 \%$ (81 of 126). This is in accordance with the literature, where downstaging rates of $28-62 \%$ are reported $[58,59]$. Patients with BD-0 experienced a T-level response rate of $82.6 \%$ (38 of 46) compared to those with BD-1 of $33.8 \%$ (27 of 80 ; $P<0.001)$.
Bhangu et al., who investigated the association between EMT (which is thought to be the underlying molecular mechanism behind tumor budding) and non-response in a cohort of 69 (primary: $n=54$ and recurrence: $n=15$ ) rectal cancer patients who were curatively treated with nCRT and surgery, reported a non-response rate of $65 \%$. In the subgroup analysis of 54 primary cancers, all EMT biomarkers and tumor budding have been investigated in 45 patients and found to be positive in 24 of 31 non-responders (77.4\%) compared to 1 of 14 responders $(7.1 \% ; P<0.001)$, indicating a significant association with non-response [24]. Huebner et al., who investigated the impact of pathologic parameters in a cohort of 237 nCRT-treated rectal cancer patients, were the first to systematically study tumor budding in rectal cancer after neoadjuvant therapy. They found tumor budding to be a significant predictor of survival [37]. In contrast to our findings of a budding rate of $63 \%$, they reported a budding rate of only $10 \%$. This discrepancy may be explained by their definition of tumor budding, which was positive if any field (counted at $200 \times$ magnification using a routine $\mathrm{H} \& \mathrm{E}$ staining) had 10 or more buds, a method described by Ueno et al. [60]. In our cohort, tumor budding was defined as positive (moderate or severe budding, BD-1) if one or more foci in an average of $10 \mathrm{HPF}$ were observed [46, 47, 61, 62]. This method of defining tumor budding can be contrasted to that described by Sannier et al., who only recorded the absence or presence of tumor buds without any cut-off value to define tumor budding. They explained this by the ease of the applicability and the association of even low numbers of tumor buds with adverse effects on outcome in nCRT-treated patients [38]. Irrespective of the varying tumor budding rates, the abovementioned three studies- to the authors' best knowledge - are the only existing studies that explicitly investigated the prognostic role of tumor budding in nCRT-treated rectal cancer patients (Table 6; [24, $37,38]$ ). Jessberger et al. demonstrated the prognostic value of tumor cell growth patterns (which included tumor budding) in predicting survival in post-CRT surgical specimens, 
Table 6 Literature review of articles investigating tumor budding in neoadjuvantly treated rectal cancer patients ${ }^{\mathrm{a}}$

\begin{tabular}{|c|c|c|c|c|c|}
\hline & Huebner et al. [37] & Du et al. [39] & Bhangu et al. [24] & Sannier et al. [38] & $\begin{array}{l}\text { Present } \\
\text { study }\end{array}$ \\
\hline Design & $\mathrm{RS}$ & $\mathrm{RS}$ & $\mathrm{RS}$ & $\mathrm{RS}$ & $\mathrm{RS}$ \\
\hline Publication year & 2012 & 2012 & 2013 & 2014 & 2018 \\
\hline Institute & $\begin{array}{l}\text { Mayo Clinic, } \\
\text { Rochester, USA }\end{array}$ & $\begin{array}{l}\text { Beijing Cancer Hospi- } \\
\text { tal China }\end{array}$ & $\begin{array}{l}\text { Imperial College, Lon- } \\
\text { don, UK }\end{array}$ & $\begin{array}{l}\text { Beaujon Hospital, } \\
\text { Clichy, France }\end{array}$ & $\begin{array}{l}\text { PMU, } \\
\text { Salzburg, } \\
\text { Austria }\end{array}$ \\
\hline Period & 1996-2006 & 2001-2005 & 2009-2011 & 2005-2010 & 2003-2012 \\
\hline Intent & Curative & Curative & Curative & Curative & Curative \\
\hline Patients $(n)$ & 237 & 96 & 69 & 113 & 128 \\
\hline Age (years) & Mean 60 & Median 57 & 14 of $54>65$ & Median 59 & Mean 64 \\
\hline Type of tumor & Primary & Primary & $\begin{array}{l}\text { Recurrent: } n=15 \\
\text { Primary: } n=54\end{array}$ & Primary & Primary \\
\hline $\begin{array}{l}\text { Tumor location } \\
\text { (from anal verge) }\end{array}$ & $\leq 12 \mathrm{~cm}$ & $\leq 1 \mathrm{~cm}$ & - & $\leq 12 \mathrm{~cm}$ & $\leq 12 \mathrm{~cm}$ \\
\hline Tumor stage & I, II, III & II, III & Locally advanced & I-IV & II, III \\
\hline $\begin{array}{l}\text { Neoadjuvant } \\
\text { therapy }\end{array}$ & CRT & RT & CRT & CRT & CRT \\
\hline Radiation scheme & Not mentioned & $\begin{array}{l}3000 \mathrm{cGy} \text { in } 10 \text { frac- } \\
\text { tions in } 2 \text { weeks } \\
(36 \mathrm{~Gy})\end{array}$ & $\begin{array}{l}\text { Fractionated, maxi- } \\
\text { mum dose of } 54 \mathrm{~Gy}\end{array}$ & $\begin{array}{l}45-50 \text { Gy over } \\
5-6 \text { weeks }\end{array}$ & $\begin{array}{l}45-50 \mathrm{~Gy} \\
\text { over } \\
5-6 \text { weeks }\end{array}$ \\
\hline $\begin{array}{l}\text { Concurrent } \\
\text { chemotherapy }\end{array}$ & $5-\mathrm{FU}$ & - & 5-FU or capecitabine & $5-\mathrm{FU}$ & $\begin{array}{l}\text { 5-FU, } \\
\text { capecitabine, } \\
\text { Oxaliplatin }\end{array}$ \\
\hline $\begin{array}{l}\text { Interval to } \\
\text { surgery (weeks) }\end{array}$ & $6-8$ & $2-3$ & $\leq 6$ & $6-9$ & $3-9$ \\
\hline $\begin{array}{l}\text { Postoperative } \\
\text { chemotherapy }\end{array}$ & $233(98.3 \%)$ & All patients & Not found & $\begin{array}{l}\text { If ypN+ staged or } \\
\text { distant metastases }\end{array}$ & $\begin{array}{l}47.9 \%(58 \\
\text { of } 121)\end{array}$ \\
\hline $\begin{array}{l}\text { Tumor budding } \\
\text { present }\end{array}$ & $24(10.1 \%)$ & $36(37.5 \%)$ & 25 of $45(55.5 \%)$ & $25(22.1 \%)$ & $81(63.2 \%)$ \\
\hline $\begin{array}{l}\text { Median follow-up } \\
\text { (years) }\end{array}$ & 3.5 & 5.9 & - & 2.9 & 7 \\
\hline Associated with & CSS, RFS & DFS & OS, CSS & LR & $\begin{array}{l}\text { DR, OR, } \\
\text { RFS }\end{array}$ \\
\hline Local recurrence & $6(2.5 \%)$ & - & - & $5(4.6 \%)$ & $6(4.7 \%)$ \\
\hline $\begin{array}{l}\text { Distant recur- } \\
\text { rence }\end{array}$ & $43(18.1 \%)$ & - & - & $30(27.8 \%)$ & $12(9.4 \%)$ \\
\hline
\end{tabular}

$C R T$ chemoradiotherapy, $C S S$ cancer-specific survival, $D F S$ disease-free survival, $D R$ distant recurrence, $G y$ Gray, $L R$ local recurrence, $O R$ overall recurrence, $O S$ overall survival, $R F S$ relapse-free survival, $R S$ retrospective, $R T$ radiotherapy.

${ }^{a}$ Not indicated Jessberger et al. [40]

but not in pretreatment biopsies [40]. Although this study group used a different technique to identify tumor budding, the alteration of cancer cells' growth pattern along the invasion front by nCRT was demonstrated, indicating potential constraints in assessing posttreatment tumor budding [40].

Tumor budding is usually assessed at the tumor invasive front, as buds are most prominent here [33]. In contrast to colorectal cancer specimens without nCRT, pathological evaluation of rectal cancer after chemoradiation is more complex. It is important to consider that residual cancer cells in nCRT-treated rectal specimens are unequally distributed in the bowel wall [63], and an invasive front is not necessarily present to correctly score tumor budding in rectal cancer after nCRT [38]. In our cohort, specimens with clear radiogenic regression (AJCC/CAP grade 0, "complete response") exhibited destruction of the tumor glandular component with subsequent fibrosis resulting in disruption of the tumor tissue, which made budding assessment more challenging, a topic first investigated and described by Du et al. [39]. Nevertheless, in the remaining regression grades (AJCC/CAP 1, 2, and 3; "moderate," "mild," and "poor" responses, respectively), the assessment of tumor budding was possible as the tumor invasive front could be clearly identified according to the $10 \mathrm{HPF}$ method [46, 47, 62]. Du et al. in their study evaluated the morphology and prognostic value of tumor budding in 96 rectal cancer patients after radiotherapy alone and consecutive curative resection. Tumor budding in irradiated specimens was found to be an 
independent factor, among others, affecting long-term disease-free survival. They further demonstrated an excellent concordance of tumor budding assessed on $\mathrm{H} \& \mathrm{E}$ and immunohistochemical stained slides of irradiated rectal cancer specimens, indicating the feasibility of tumor budding assessment on $\mathrm{H} \& \mathrm{E}$ stained slides of irradiated specimens [39].

A drawback of tumor budding assessment and reporting is the limited reproducibility and the lack of standardization with various existing techniques for assessing and classifying tumor budding, as excellently reviewed recently [64-66]. Sources of variability in the assessment of tumor budding include the optimal location for assessment (tumor front vs. within the tumor), visualization, and staining (H\&E staining vs. immunohistochemistry) of the budding cells, as well as the method of scoring (qualitative vs. quantitative) [67].

Intratumoral budding was demonstrated to be an independent prognostic factor and strongly correlated with peritumoral budding in a cohort of 511 colorectal cancer patients, supporting the future relevance of intratumoral budding, especially in preoperative rectal cancer specimens [68]. This was confirmed by a retrospective study conducted by Rogers et al., who assessed the intratumoral budding in pretreatment rectal cancer biopsies with a budding rate of $20 \%$ (18 of 89) and confirmed tumor budding to be a predictive factor for a poor pathological response to nCRT (higher ypT stage, lymph node involvement, lymphovascular invasion, and residual poorly differentiated tumors) and longterm outcome [29].

Although the evaluation of tumor budding with immunohistochemistry has improved detection rates and interobserver agreements compared to $\mathrm{H} \& \mathrm{E}$ staining, the International Tumor Budding Consensus Conference recommends tumor budding assessment using $\mathrm{H} \& \mathrm{E}$ [45]. Indeed, in some previous meta-analyses, the prognostic impact of tumor budding assessed using H\&E did not differ significantly compared to immunohistochemistry $[28,33,46,64,66]$.

Despite the existence of the aforementioned variability in the definition of how many cells constitute a tumor bud and how many buds constitute positive budding, together with the considerable interobserver variability in its reporting, most studies definitively demonstrate tumor budding as a strong negative prognostic marker in colorectal cancer [64]. Additionally, the results of the International Tumor Budding Consensus Conference (April 27-29, 2016, Bern/ Switzerland) provide optimism that an agreement on an international, evidence-based standardized scoring system for tumor budding in colorectal cancer is on the horizon [45].

There are several limitations to our study. First and foremost are the limitations inherent to retrospective analyses. The number of events in relapse-free survival may be a limitation in the interpretation of the multivariate analysis. In our cohort study, the completeness of follow-up in the two groups (BD-0 and BD-1) was $88 \%$ and $81 \%$, indicating data incompleteness and a possible bias in the analysis.

To date, the assumption that a tumor budding status following nCRT reflects its dimension before any treatment is based on one study only and should be validated in larger cohorts at other institutions [29]. Nonetheless, in the row of the few reports dealing with the role of tumor budding in neoadjuvantly treated rectal cancer patients, the present analysis provides robust data with the longest follow-up time (median: 7 years, with each patient followed at least for 5 years) and the most current treatment era (until the end of 2012) and thus treatment regimen.

\section{Conclusion}

Our data confirm the predictive value of tumor budding persistence after neoadjuvant chemoradiotherapy and, hence, putatively for the response towards nCRT in locally advanced rectal cancer patients. In addition to the established predictive parameters (TNM classification and tumor regression grading), tumor budding is accessible in pretreatment biopsy specimens and could therefore, at least hypothetically, serve as a predictor of non-response to nCRT, also providing a possibility to stratify putative non-responders into an individualized nCRT regimen.

Further efforts are needed to gather scientific evidence to validate the promising role of tumor budding and to gain a greater understanding of the underlying molecular mechanisms behind EMT and tumor budding. This information will help to improve the multidisciplinary treatment of locally advanced rectal cancer patients.

Funding Open access funding provided by Paracelsus Medical University.

Conflict of interest T. Jäger, D. Neureiter, M. Fallaha, P. Schredl, T. Kiesslich, R. Urbas, E. Klieser, J. Holzinger, F. Sedlmayer, K. Emmanuel, and A. Dinnewitzer declare that they have no conflict of interest.

Open Access This article is distributed under the terms of the Creative Commons Attribution 4.0 International License (http:// creativecommons.org/licenses/by/4.0/), which permits unrestricted use, distribution, and reproduction in any medium, provided you give appropriate credit to the original author(s) and the source, provide a link to the Creative Commons license, and indicate if changes were made.

\section{References}

1. Kapiteijn E, Marijnen CA, Nagtegaal ID, Putter H, Steup WH, Wiggers T, Rutten HJ, Pahlman L, Glimelius B, van Krieken JH, Leer JW, van de Velde CJ, Dutch Colorectal Cancer Group (2001) Preoperative radiotherapy combined with total mesorectal excision for 
resectable rectal cancer. N Engl J Med 345:638-646. https://doi. org/10.1056/NEJMoa010580

2. Sauer R, Becker H, Hohenberger W, Rödel C, Wittekind C, Fietkau R, Martus P, Tschmelitsch J, Hager E, Hess CF, Karstens JH, Liersch T, Schmidberger H, Raab R, German Rectal Cancer Study Group (2004) Preoperative versus postoperative chemoradiotherapy for rectal cancer. N Engl J Med 351:1731-1740. https://doi. org/10.1056/NEJMoa040694

3. Ma B, Gao P, Wang H, Xu Q, Song Y, Huang X, Sun J, Zhao J, Luo J, Sun Y, Wang Z (2017) What has preoperative radio(chemo)therapy brought to localized rectal cancer patients in terms of perioperative and long-term outcomes over the past decades? A systematic review and meta-analysis based on 41,121 patients. Int J Cancer 141:1052-1065. https://doi.org/10.1002/ijc. 30805

4. Bosset JF, Collette L, Calais G, Mineur L, Maingon P, RadosevicJelic L, Daban A, Bardet E, Beny A, Ollier JC, EORTC Radiotherapy Group Trial 22921 (2006) Chemotherapy with preoperative radiotherapy in rectal cancer. N Engl J Med 355:1114-1123. https:// doi.org/10.1056/NEJMoa060829

5. Sauer R, Liersch T, Merkel S, Fietkau R, Hohenberger W, Hess C, Becker H, Raab HR, Villanueva MT, Witzigmann H, Wittekind C, Beissbarth T, Rödel C (2012) Preoperative versus postoperative chemoradiotherapy for locally advanced rectal cancer: results of the German CAO/ARO/AIO-94 randomized phase III trial after a median follow-up of 11 years. J Clin Oncol 30:1926-1933. https://doi. org/10.1200/JCO.2011.40.1836

6. Fokas E, Liersch T, Fietkau R, Hohenberger W, Beissbarth T, Hess C, Becker H, Ghadimi M, Mrak K, Merkel S, Raab HR, Sauer R, Wittekind C, Rödel C (2014) Tumor regression grading after preoperative chemoradiotherapy for locally advanced rectal carcinoma revisited: updated results of the CAO/ARO/AIO-94 trial. J Clin Oncol 32:1554-1562. https://doi.org/10.1200/JCO.2013.54.3769

7. Folkesson J, Birgisson H, Pahlman L, Cedermark B, Glimelius B, Gunnarsson U (2005) Swedish Rectal Cancer Trial: long lasting benefits from radiotherapy on survival and local recurrence rate. J Clin Oncol 23:5644-5650. https://doi.org/10.1200/JCO.2005.08. 144

8. van Gijn W, Marijnen CA, Nagtegaal ID, Kranenbarg EM, Putter H, Wiggers T, Rutten HJ, Påhlman L, Glimelius B, van de Velde CJ, Dutch Colorectal Cancer Group (2011) Preoperative radiotherapy combined with total mesorectal excision for resectable rectal cancer: 12-year follow-up of the multicentre, randomised controlled TME trial. Lancet Oncol 12:575-582. https://doi.org/10. 1016/S1470-2045(11)70097-3

9. Gérard JP, Conroy T, Bonnetain F, Bouché O, Chapet O, ClosonDejardin MT, Untereiner M, Leduc B, Francois E, Maurel J, Seitz JF, Buecher B, Mackiewicz R, Ducreux M, Bedenne L (2006) Preoperative radiotherapy with or without concurrent fluorouracil and leucovorin in T3-4 rectal cancers: results of FFCD 9203. J Clin Oncol 24:4620-4625. https://doi.org/10.1200/JCO.2006.06.7629

10. Bosset JF, Calais G, Mineur L, Maingon P, Stojanovic-Rundic S, Bensadoun RJ, Bardet E, Beny A, Ollier JC, Bolla M, Marchal D, Van Laethem JL, Klein V, Giralt J, Clavère P, Glanzmann C, Cellier P, Collette L, EORTC Radiation Oncology Group (2014) Fluorouracil-based adjuvant chemotherapy after preoperative chemoradiotherapy in rectal cancer. Long-term results of the EORTC 22921 randomised study. Lancet Oncol 15:184-190. https://doi.org/10. 1016/S1470-2045(13)70599-0

11. Ngan SY, Burmeister B, Fisher RJ, Solomon M, Goldstein D, Joseph D, Ackland SP, Schache D, McClure B, McLachlan SA, McKendrick J, Leong T, Hartopeanu C, Zalcberg J, Mackay J (2012) Randomized trial of short-course radiotherapy versus longcourse chemoradiation comparing rates of local recurrence in patients with T3 rectal cancer: Trans-Tasman Radiation Oncology
Group trial 01.04. J Clin Oncol 30:3827-3833. https://doi.org/10. 1200/JCO.2012.42.9597

12. Erlandsson J, Holm T, Pettersson D, Berglund A, Cedermark B, Radu C, Johansson H, Machado M, Hjern F, Hallböök O, Syk I, Glimelius B, Martling A (2017) Optimal fractionation of preoperative radiotherapy and timing to surgery for rectal cancer (Stockholm III): a multicentre, randomised, non-blinded, phase 3, non-inferiority trial. Lancet Oncol 18:336-346. https://doi.org/10.1016/S14702045(17)30086-4

13. Deng Y, Chi P, Lan P, Wang L, Chen W, Cui L, Chen D, Cao J, Wei H, Peng X, Huang Z, Cai G, Zhao R, Huang Z, Xu L, Zhou H, Wei Y, Zhang H, Zheng J, Huang Y, Zhou Z, Cai Y, Kang L, Huang M, Peng J, Ren D, Wang J (2016) Modified FOLFOX6 with or without radiation versus fluorouracil and leucovorin with radiation in neoadjuvant treatment of locally advanced rectal cancer: initial results of the Chinese FOWARC multicenter, open-label, randomized three-arm phase III trial. J Clin Oncol 34:3300-3307. https://doi. org/10.1200/JCO.2016.66.6198

14. Fokas E, Rödel C (2017) Optimales Fraktionierungsschema und Zeitintervall zwischen Radiotherapie und Operation beim Rektumkarzinom: Die multizentrische, randomisierte Stockholm-IIIStudie. Strahlenther Onkol 193:761-762. https://doi.org/10.1007/ s00066-017-1181-2

15. Rödel C, Fokas E (2017) Inklusion von Oxaliplatin in die multimodale Behandlung des lokal fortgeschrittenen Rektumkarzinoms. Strahlenther Onkol 193:168-170. https://doi.org/10.1007/s00066016-1090-9

16. Yang YJ, Cao L, Li ZW, Zhao L, Wu HF, Yue D, Yang JL, Zhou ZR, Liu SX (2016) Fluorouracil-based neoadjuvant chemoradiotherapy with or without oxaliplatin for treatment of locally advanced rectal cancer: an updated systematic review and meta-analysis. Oncotarget 7:45513-45524. https://doi.org/10.18632/oncotarget.9995

17. Gani C, Zips D (2017) Zeitintervall zwischen neoadjuvanter Radiochemotherapie und Operation beim Rektumkarzinom: Kein Einfluss auf die pathologische Komplettremissionsrate? Strahlenther Onkol 193:91-92. https://doi.org/10.1007/s00066-016-1080-y

18. Rödel C, Liersch T, Becker H, Fietkau R, Hohenberger W, Hothorn T, Graeven U, Arnold D, Lang-Welzenbach M, Raab HR, Sülberg H, Wittekind C, Potapov S, Staib L, Hess C, Weigang-Köhler K, Grabenbauer GG, Hoffmanns H, Lindemann F, SchlenskaLange A, Folprecht G, Sauer R, German Rectal Cancer Study Group (2012) Preoperative chemoradiotherapy and postoperative chemotherapy with fluorouracil and oxaliplatin versus fluorouracil alone in locally advanced rectal cancer: initial results of the German CAO/ARO/AIO-04 randomised phase 3 trial. Lancet Oncol 13:679-687. https://doi.org/10.1016/S1470-2045(12)70187-0

19. Rödel C, Graeven U, Fietkau R, Hohenberger W, Hothorn T, Arnold D, Hofheinz RD, Ghadimi M, Wolff HA, Lang-Welzenbach M, Raab HR, Wittekind C, Ströbel P, Staib L, Wilhelm M, Grabenbauer GG, Hoffmanns H, Lindemann F, Schlenska-Lange A, Folprecht G, Sauer R, Liersch T, German Rectal Cancer Study Group (2015) Oxaliplatin added to fluorouracil-based preoperative chemoradiotherapy and postoperative chemotherapy of locally advanced rectal cancer (the German CAO/ARO/AIO-04 study): final results of the multicentre, open-label, randomised, phase 3 trial. Lancet Oncol 16:979-989. https://doi.org/10.1016/S1470-2045(15)00159-X

20. Lefevre JH, Mineur L, Kotti S, Rullier E, Rouanet P, de Chaisemartin C, Meunier B, Mehrdad J, Cotte E, Desrame J, Karoui M, Benoist S, Kirzin S, Berger A, Panis Y, Piessen G, Saudemont A, Prudhomme M, Peschaud F, Dubois A, Loriau J, Tuech JJ, Meurette G, Lupinacci R, Goasgen N, Parc Y, Simon T, Tiret E (2016) Effect of Interval (7 or 11 weeks) Between Neoadjuvant Radiochemotherapy and Surgery on Complete Pathologic Response in Rectal Cancer: A Multicenter, Randomized, Controlled Trial (GRECCAR-6). J Clin Oncol 34:3773-3780. https://doi.org/10.1200/JCO.2016.67. 6049 
21. Bujko K, Wyrwicz L, Rutkowski A, Malinowska M, Pietrzak L, Kryński J, Michalski W, Olędzki J, Kuśnierz J, Zając L, Bednarczyk M, Szczepkowski M, Tarnowski W, Kosakowska E, Zwoliński J, Winiarek M, Wiśniowska K, Partycki M, Bęczkowska K, Polkowski W, Styliński R, Wierzbicki R, Bury P, Jankiewicz M, Paprota K, Lewicka M, Ciseł B, Skórzewska M, Mielko J, Bębenek M, Maciejczyk A, Kapturkiewicz B, Dybko A, Hajac Ł, Wojnar A, Leśniak T, Zygulska J, Jantner D, Chudyba E, Zegarski W, LasJankowska M, Jankowski M, Kołodziejski L, Radkowski A, Żelazowska-Omiotek U, Czeremszyńska B, Kępka L, Kolb-Sielecki J, Toczko Z, Fedorowicz Z, Dziki A, Danek A, Nawrocki G, Sopyło R, Markiewicz W, Kędzierawski P, Wydmański J, Polish Colorectal Study Group (2016) Long-course oxaliplatin-based preoperative chemoradiation versus $5 \times 5 \mathrm{~Gy}$ and consolidation chemotherapy for cT4 or fixed cT3 rectal cancer: results of a randomized phase III study. Ann Oncol 27:834-842. https://doi.org/10.1093/annonc/ mdw062

22. Maas M, Nelemans PJ, Valentini V, Das P, Rödel C, Kuo LJ, Calvo FA, García-Aguilar J, Glynne-Jones R, Haustermans K, Mohiuddin M, Pucciarelli S, Small W Jr, Suárez J, Theodoropoulos G, Biondo S, Beets-Tan RG, Beets GL (2010) Long-term outcome in patients with a pathological complete response after chemoradiation for rectal cancer: a pooled analysis of individual patient data. Lancet Oncol 11:835-844. https://doi.org/10.1016/S1470-2045(10)70172-8

23. Ferrari L, Fichera A (2015) Neoadjuvant chemoradiation therapy and pathological complete response in rectal cancer. Gastroenterol Rep (oxf) 3:277-288. https://doi.org/10.1093/gastro/gov039

24. Bhangu A, Wood G, Brown G, Darzi A, Tekkis P, Goldin R (2014) The role of epithelial mesenchymal transition and resistance to neoadjuvant therapy in locally advanced rectal cancer. Colorectal Dis 16:133-143. https://doi.org/10.1111/codi.12482

25. Edge S, Fritz A, Byrd D, Greene F, Compton C, Trotti A (2010) AJCC cancer staging manual, 7th edn. Springer, New York

26. Jäger T, Neureiter D, Urbas R, Klieser E, Hitzl W, Emmanuel K, Dinnewitzer A (2017) Applicability of American Joint Committee on Cancer and College of American pathologists regression grading system in rectal cancer. Dis Colon Rectum 60:815-826. https://doi. org/10.1097/DCR.0000000000000806

27. Fokas E, Ströbel P, Fietkau R, Ghadimi M, Liersch T, Grabenbauer GG, Hartmann A, Kaufmann M, Sauer R, Graeven U, Hoffmanns H, Raab HR, Hothorn T, Wittekind C, Rödel C, German Rectal Cancer Study Group (2017) Tumor regression grading after preoperative chemoradiotherapy as a prognostic factor and individual-level surrogate for disease-free survival in rectal cancer. J Natl Cancer Inst 109(12).https://doi.org/10.1093/jnci/djx095

28. De Smedt L, Palmans S, Sagaert X (2016) Tumour budding in colorectal cancer: what do we know and what can we do? Virchows Arch 468:397-408. https://doi.org/10.1007/s00428-015-1886-5

29. Rogers AC, Gibbons D, Hanly AM, Hyland JM, O'Connell PR, Winter DC, Sheahan K (2014) Prognostic significance of tumor budding in rectal cancer biopsies before neoadjuvant therapy. Mod Pathol 27:156-162. https://doi.org/10.1038/modpathol.2013.124

30. Prall F, Ostwald C (2007) Tumour budding in colorectal carcinoma. Histopathology 50:151-162. https://doi.org/10.1111/j.1365-2559. 2006.02551.x

31. Bhangu A, Wood G, Mirnezami A, Darzi A, Tekkis P, Goldin R (2012) Epithelial mesenchymal transition in colorectal cancer: Seminal role in promoting disease progression and resistance to neoadjuvant therapy. Surg Oncol 21:316-323. https://doi.org/10. 1016/j.suronc.2012.08.003

32. Kalluri R, Weinberg RA (2009) The basics of epithelial-mesenchymal transition. J Clin Invest 119:1420-1428. https://doi.org/10. 1172/JCI39104

33. Mitrovic B, Schaeffer DF, Riddell RH, Kirsch R (2012) Tumor budding in colorectal carcinoma: time to take notice. Mod Pathol 25:1315-1325. https://doi.org/10.1038/modpathol.2012.94
34. Acloque H, Adams MS, Fishwick K, Bronner-Fraser M, Nieto MA (2009) Epithelial-mesenchymal transitions: the importance of changing cell state in development and disease. J Clin Invest 119:1438-1449. https://doi.org/10.1172/JCI38019

35. Mani SA, Guo W, Liao MJ, Eaton EN, Ayyanan A, Zhou AY, Brooks M, Reinhard F, Zhang CC, Shipitsin M, Campbell LL, Polyak K, Brisken C, Yang J, Weinberg RA (2008) The epithelialmesenchymal transition generates cells with properties of stem cells. Cell 133:704-715. https://doi.org/10.1016/j.cell.2008.03.027

36. Morel AP, Lièvre M, Thomas C, Hinkal G, Ansieau S, Puisieux A (2008) Generation of breast cancer stem cells through epithelial-mesenchymal transition. PLoS ONE 3:e2888. https://doi.org/ 10.1371/journal.pone.0002888

37. Huebner M, Wolff BG, Smyrk TC, Aakre J, Larson DW (2012) Partial pathologic response and nodal status as most significant prognostic factors for advanced rectal cancer treated with preoperative chemoradiotherapy. World J Surg 36:675-683. https://doi.org/10. 1007/s00268-011-1409-8

38. Sannier A, Lefèvre JH, Panis Y, Cazals-Hatem D, Bedossa P, Guedj N (2014) Pathological prognostic factors in locally advanced rectal carcinoma after neoadjuvant radiochemotherapy: analysis of 113 cases. Histopathology 65:623-630. https://doi.org/10.1111/ his. 12432

39. Du C, Xue W, Li J, Cai Y, Gu J (2012) Morphology and prognostic value of tumor budding in rectal cancer after neoadjuvant radiotherapy. Hum Pathol 43:1061-1067. https://doi.org/10.1016/j.humpath. 2011.07.026

40. Jessberger J, Erlenbach-Wünsch K, Posselt R, Haderlein M, Agaimy A, Fietkau R, Hartmann A, Distel L (2017) Combination of growth pattern and tumor regression identifies a high-risk group in neoadjuvant treated rectal cancer patients. J Dig Dis 18:283-291. https://doi.org/10.1111/1751-2980.12471

41. Ofner D, Devries AF, Schaberl-Moser R, Greil R, Rabl H, Tschmelitsch J, Zitt M, Kapp KS, Fastner G, Keil F, Eisterer W, Jäger R, Offner F, Gnant M, Thaler J, TAKO 05/ABCSG R-02 Trial Investigators (2011) Preoperative oxaliplatin, capecitabine, and external beam radiotherapy in patients with newly diagnosed, primary operable, $\mathrm{cT}_{3} \mathrm{NxM} 0$, low rectal cancer: a phase II study. Strahlenther Onkol 187:100-107. https://doi.org/10.1007/s00066-010-2182-6

42. Kogler P, DeVries AF, Eisterer W, Thaler J, Sölkner L, Öfner D, TAKO 05/ABCSG R-02 Trial Investigators (2018) Intensified preoperative chemoradiation by adding oxaliplatin in locally advanced, primary operable $\left(\mathrm{cT}_{3} \mathrm{NxM} 0\right)$ rectal cancer: Impact on long-term outcome. Results of the phase II TAKO 05/ABCSG R-02 trial. Strahlenther Onkol 194:41-49. https://doi.org/10.1007/ s00066-017-1219-5

43. Jäger T, Nawara C, Neureiter D, Holzinger J, Öfner-Velano D, Dinnewitzer A (2015) Impact of anastomotic leakage on long-term survival in mid-to-low rectal cancer. Chirurg 86:1072-1082. https:// doi.org/10.1007/s00104-015-0090-0

44. Austrian Society of Pathology Qualitätsstandards in der Pathologie. http://www.pathology.at/images/stories/PDF/Qualitaetsstandards/ QS_Kolon_Rektum_V1.0.pdf. Accessed 11 Mar 2017

45. Lugli A, Kirsch R, Ajioka Y, Bosman F, Cathomas G, Dawson H, El Zimaity H, Fléjou JF, Hansen TP, Hartmann A, Kakar S, Langner C, Nagtegaal I, Puppa G, Riddell R, Ristimäki A, Sheahan K, Smyrk T, Sugihara K, Terris B, Ueno H, Vieth M, Zlobec I, Quirke P (2017) Recommendations for reporting tumor budding in colorectal cancer based on the International Tumor Budding Consensus Conference (ITBCC) 2016. Mod Pathol 30:1299-1311. https://doi.org/10.1038/ modpathol.2017.46

46. Koelzer VH, Zlobec I, Lugli A (2016) Tumor budding in colorectal cancer-ready for diagnostic practice? Hum Pathol 47:4-19. https://doi.org/10.1016/j.humpath.2015.08.007

47. Horcic M, Koelzer VH, Karamitopoulou E, Terracciano L, Puppa G, Zlobec I, Lugli A (2013) Tumor budding score based on 10 high- 
power fields is a promising basis for a standardized prognostic scoring system in stage II colorectal cancer. Hum Pathol 44:697-705. https://doi.org/10.1016/j.humpath.2012.07.026

48. Dinnewitzer A, Jäger T, Nawara C, Buchner S, Wolfgang H, Öfner D (2013) Cumulative incidence of permanent stoma after sphincter preserving low anterior resection of mid and low rectal cancer. Dis Colon Rectum 56:1134-1142. https://doi.org/10.1097/DCR. 0b013e31829ef472

49. Clark TG, Altman DG, De Stavola BL (2002) Quantification of the completeness of follow-up. Lancet 359:1309-1310. https://doi.org/ 10.1016/S0140-6736(02)08272-7

50. Mace AG, Pai RK, Stocchi L, Kalady MF (2015) American Joint Committee on Cancer and College of American Pathologists regression grade: a new prognostic factor in rectal cancer. Dis Colon Rectum 58:32-44. https://doi.org/10.1097/DCR.0000000000000266

51. Cao H, Xu E, Liu H, Wan L, Lai M (2015) Epithelial-mesenchymal transition in colorectal cancer metastasis: a system review. Pathol Res Pract 211:557-569. https://doi.org/10.1016/j.prp.2015.05.010

52. Kirchner T, Brabletz T (2000) Patterning and nuclear $\beta$-Catenin expression in the colonic adenoma-carcinoma sequence: analogies with embryonic gastrulation. Am J Pathol 157:1113-1121. https:// doi.org/10.1016/S0002-9440(10)64626-3

53. Zlobec I, Lugli A (2010) Epithelial mesenchymal transition and tumor budding in aggressive colorectal cancer: tumor budding as oncotarget. Oncotarget 1:651-661. https://doi.org/10.18632/ oncotarget.199

54. Wang L, Zhang XM, Li Z, Liu XJ, Chai J, Zhang GY, Cheng YF (2013) Overexpression of nuclear $\beta$-catenin in rectal adenocarcinoma is associated with radioresistance. World J Gastroenterol 19:6876-6882. https://doi.org/10.3748/wjg.v19.i40.6876

55. Takahashi H, Nakamura K, Usami A, Tsuruta T, Hashimura M, Matsumoto T, Saegusa M (2017) Possible role of nuclear $\beta$-catenin in resistance to preoperative chemoradiotherapy in locally advanced rectal cancer. Histopathology 71:227-237. https://doi.org/10.1111/ his. 13227

56. Kawamoto A, Yokoe T, Tanaka K, Saigusa S, Toiyama Y, Yasuda H, Inoue Y, Miki C, Kusunoki M (2012) Radiation induces epithelial-mesenchymal transition in colorectal cancer cells. Oncol Rep 27:51-57. https://doi.org/10.3892/or.2011.1485

57. Tato-Costa J, Casimiro S, Pacheco T, Pires R, Fernandes A, Alho I, Pereira P, Costa P, Castelo HB, Ferreira J, Costa L (2016) Therapyinduced cellular senescence induces epithelial-to-mesenchymal transition and increases invasiveness in rectal cancer. Clin Colorectal Cancer 15:170-178.e3. https://doi.org/10.1016/j.clcc.2015.09. 003

58. Janjan NA, Khoo VS, Abbruzzese J, Pazdur R, Dubrow R, Cleary KR, Allen PK, Lynch PM, Glober G, Wolff R, Rich TA, Skibber J (1999) Tumor downstaging and sphincter preservation with preop- erative chemoradiation in locally advanced rectal cancer: the M. D. Anderson Cancer Center experience. Int J Radiat Oncol Biol Phys 44:1027-1038. https://doi.org/10.1016/S0360-3016(99)00099-1

59. Medich D, McGinty J, Parda D, Karlovits S, Davis C, Caushaj P, Lembersky B (2001) Preoperative chemoradiotherapy and radical surgery for locally advanced distal rectal adenocarcinoma. Dis Colon Rectum 44:1123-1128. https://doi.org/10.1007/ BF02234632

60. Ueno H, Mochizuki H, Shinto E, Hashiguchi Y, Hase K, Talbot IC (2002) Histologic indices in biopsy specimens for estimating the probability of extended local spread in patients with rectal carcinoma. Cancer 94:2882-2891. https://doi.org/10.1002/cncr.10551

61. Lugli A, Karamitopoulou E, Zlobec I (2012) Tumour budding: a promising parameter in colorectal cancer. Br J Cancer 106:17131717. https://doi.org/10.1038/bjc.2012.127

62. Karamitopoulou E, Zlobec I, Kölzer V, Kondi-Pafiti A, Patsouris ES, Gennatas K, Lugli A (2013) Proposal for a 10-high-powerfields scoring method for the assessment of tumor budding in colorectal cancer. Mod Pathol 26:295-301. https://doi.org/10.1038/ modpathol.2012.155

63. Tranchart H, Lefèvre JH, Svrcek M, Flejou JF, Tiret E, Parc Y (2013) What is the incidence of metastatic lymph node involvement after significant pathologic response of primary tumor following neoadjuvant treatment for locally advanced rectal cancer? Ann Surg Oncol 20:1551-1559. https://doi.org/10.1245/s10434-012-2773-9

64. Rogers AC, Winter DC, Heeney A, Gibbons D, Lugli A, Puppa G, Sheahan K (2016) Systematic review and meta-analysis of the impact of tumour budding in colorectal cancer. $\mathrm{Br} \mathrm{J}$ Cancer 115:831-840. https://doi.org/10.1038/bjc.2016.274

65. Grigore AD, Jolly MK, Jia D, Farach-Carson MC, Levine H (2016) Tumor budding: the name is EMT. Partial EMT. J Clin Med 5(5).https://doi.org/10.3390/jcm5050051

66. van Wyk HC, Park J, Roxburgh C, Horgan P, Foulis A, McMillan DC (2015) The role of tumour budding in predicting survival in patients with primary operable colorectal cancer: a systematic review. Cancer Treat Rev 41:151-159. https://doi.org/10.1016/j.ctrv.2014. 12.007

67. Ohtsuki K, Koyama F, Tamura T, Enomoto Y, Fujii H, Mukogawa T, Nakagawa T, Uchimoto K, Nakamura S, Nonomura A, Nakajima Y (2008) Prognostic value of Immunohistochemical analysis of tumor budding in colorectal carcinoma. Anticancer Res 28:1831-1836

68. Lugli A, Vlajnic T, Giger O, Karamitopoulou E, Patsouris ES, Peros G, Terracciano LM, Zlobec I (2011) Intratumoral budding as a potential parameter of tumor progression in mismatch repairproficient and mismatch repair-deficient colorectal cancer patients. Hum Pathol 42:1833-1840. https://doi.org/10.1016/j.humpath. 2011.02.010 


\section{Affiliations}

Tarkan Jäger $^{1}$ (D) - Daniel Neureiter ${ }^{2}$ Mohammad Fallaha ${ }^{3} \cdot$ Philipp Schredl $^{1} \cdot$ Tobias Kiesslich $^{4,5}$.

Romana Urbas ${ }^{2} \cdot$ Eckhard Klieser $^{2} \cdot$ Josef Holzinger $^{1} \cdot$ Felix Sedlmayer $^{6} \cdot$ Klaus Emmanuel $^{1} \cdot$ Adam Dinnewitzer $^{1}$

1 Department of Surgery, Paracelsus Medical University, Muellner Hauptstraße 48, 5020 Salzburg, Austria

2 Institute of Pathology, Paracelsus Medical University, Muellner Hauptstraße 48, 5020 Salzburg, Austria

3 Faculty of Medicine, Imperial College School of Medicine, South Kensington, London, SW7 2AZ, UK
4 Laboratory for Tumor Biology and Experimental Therapies (TREAT), Institute for Physiology and Pathophysiology, Salzburg, Austria

5 Department of Internal Medicine, Paracelsus Medical University, Muellner Hauptstraße 48, 5020 Salzburg, Austria

6 Department of Radiotherapy and Radiation Oncology, Paracelsus Medical University, Muellner Hauptstraße 48, 5020 Salzburg, Austria 